\title{
Monitoring Spatial Growth of Educational Institution using GIS: A Focus on Federal University of Technology Akure, Nigeria
}

\author{
Micheal Ajide Oyinloye \\ Department of Urban and Regional Planning, School of Environmental Technology, Federal University of Technology Akure, \\ Nigeria
}

\begin{abstract}
Land use/ land cover changes is an important components in understanding the interaction of human activities with its environment, therefore it is necessary to analyze such change. The land use/landcover dynamics of Federal University of Technology Akure(FUTA) for a period of sixteen years was analyzed using Multi-temporal and Multi-source image of LandSat (TM) of 1986, LandSat (ETM+) of 2002and Quick bird satellite image of 2012. Maximum likelihood (MAL) supervised digital image classification method was employed using ILWIS 3.2 and Arcview 3.1 GIS software. Eight landcover/landuse classes were created: Built up area, Dense forest, Bareland, Exposed soil, Forest reserves, Gulley forest, Light forest and Rock-out crop. Change information was derived by comparing the classified maps. The results showed that the landcover in the study area has changed during the periods especially the built-up area has increased rapidly for the periods ( 1986- 2012). The results also show increase the bareland, exposed rock out crops while forest reserves, gulley forest and light forest decrease between the same periods. Based on exponential growth formulae, the future prediction of the landuse and landcover change and its subsequent development was modeled between 2012 and 2032. These results could help in providing information for decision and planning purpose and also provide management strategies initiatives that are crucial for such expansion in the study area.
\end{abstract}

Key Words: Landcover/landuse, maximum likelihood, satellite data, Multi-temporal

\section{Introduction}

Land use refers to the activity, economic purpose, intended use and or management strategy placed on the land-cover type(s) by human agents or land managers. Land cover refers to the characteristics and surface cover of the earth surface as represented by vegetation, water, bare earth, impervious surface and other physical features of the land (John et al. 2003). When used together, land cover generally refers to the categorization or classification of human activities and natural elements on the landscape within a specified time frame based on established scientific methods of appropriate source materials (John et al. 2003)

Land use change occurs when the use to which land is put in different from what it was in past. For instance, an open space or forested area could turn into a built -up area. Therefore, land use and landcover changes play an important role in local and regional environment condition of a particular territory and they are linked to global environmental change. Cities in most developing countries like Nigeria have been undergoing unprecedented changes both in population and spatial extent (Adeboyejo and Abolade, 2006) and as a result are faced with a variety of problems such as uncoordinated land development, conflicting landuses, high densities in certain parts of the urban area and the absence of adequate road network which could ensure intra-urban mobility within the city.

Several researchers have employed various methods or techniques for landuse and landcover change detection which include, post classification change detection multidate principal component analysis and RGB-NDIV colour composite change detection.(Zhi-Yong et al 2005) used image processing and analysis in a GIS environment to assess spatial change in urban land use patterns and population distributions. Here, unsupervised classification was used to classify the images into land use classes. With Census data in a GIS, census polygon was constructed into various sets of units, and then comparison made with the classified image by proportion in surface. Similarly studies carried out by Peng and Howarth (2004) in Shaoxing City in China using Satellite imageries for the year 1984, 1997 and 2000, one of the goals of the study was to produce a land use map of Shaoxing City and its surroundings. The results show that there are undoubtedly a lot of changes that occurred between 1984 and 1997 when compared with those of 2000, 
due to the sufficient time gap. A similar approach was adopted by Weng (1999) for evaluation of urban expansion where the extracted build-up areas were also overlaid to obtain the expansion image. The buffer function in GIS was used to generate a buffer image to show the proximity of the urban expansion to the major roads of the study area. Zubair (2006) examined the use of GIS and Remote Sensing in mapping landuse and landcover in Ilorin, Nigeria between 1972 and 2001 to detect the changes that has taken place in this status between these periods. He attempted at projecting the observed landuse/ landcover in the next 14years.One of the most powerful functions of Geographical Information System (GIS) is the ability to synthesize spatial data from a variety of sources. Through functions such as aggregation, buffering, overlay and spatial query, GIS users can easily merge data on different units and change scales in a way that is relatively easy and transparent (Carol et al, 2006). Researchers have seen Geographic Information system as set valuable tools for collecting, storing, retrieving at will, frame forming, analyzing and displaying spatial data from the world. The objectives of this study include:

i. To identify the various landuse and landcover classes on remotely sensed data;

ii. To calculate and quantify the basic land use/land cover dynamics of the area from 1986 to 2002 to 2012;

iii. Determine the extent of expansion within the study area and peri-urban areas. iv. Adopt the exponential growth formulae; $A F=A b(1+\% / 100) f-b,($ where $A$ is the

Area, $\mathrm{f}$ is the future, $\mathrm{b}$ is the base year and $\%$ is the ratio of change for projecting urban expansion and landuse types) to project the growth and landuse change of the study area to year 2032;

v. Examine the major determinant (socioeconomic) factors that affect spatial expansion and the landuse types and the rate of urban growth in FUTA and its surrounding areas.

\section{The Study Area}

Akure became the capital of Ondo State in 1976. It lies on latitude $7^{0} 5$, North of the Equator and longitude $5^{0} 15^{\prime}$ East of the Greenwich Meridian. It is about $370 \mathrm{~m}$ above the sea level, is situated within a 48kilometer radius to major towns in Ondo State, viz Ondo to the South, Owo to the East and Iju/Itaogbolu to the North. Easy access and geographical centrality of Akure to these towns have enhanced the growth prospects of the city (see figures 1, 2, 3). The population of Akure in 1963 was put 71,006 and by 1999, the total population had risen to 239,124 (NPC, 1996). By the year 2006, the population had increased to 340,021 (NPC, 2006). The increase in annual growth of the population had been tied to the administrative role of the town and its long standing role as a centre of economic activities attracting a large spectrum of immigrants into it.

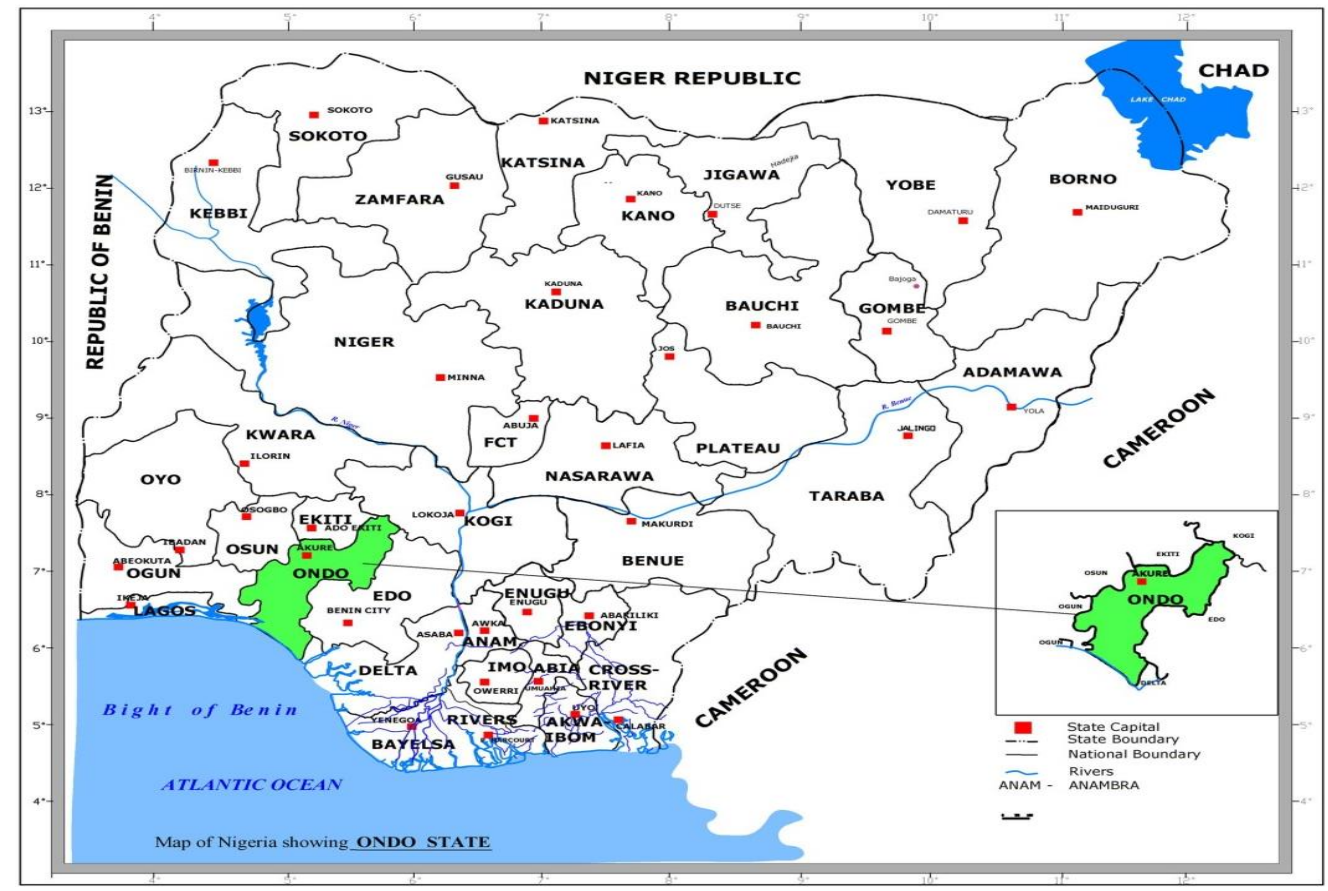

Figure 1. Map of Nigeria Showing Ondo State. 


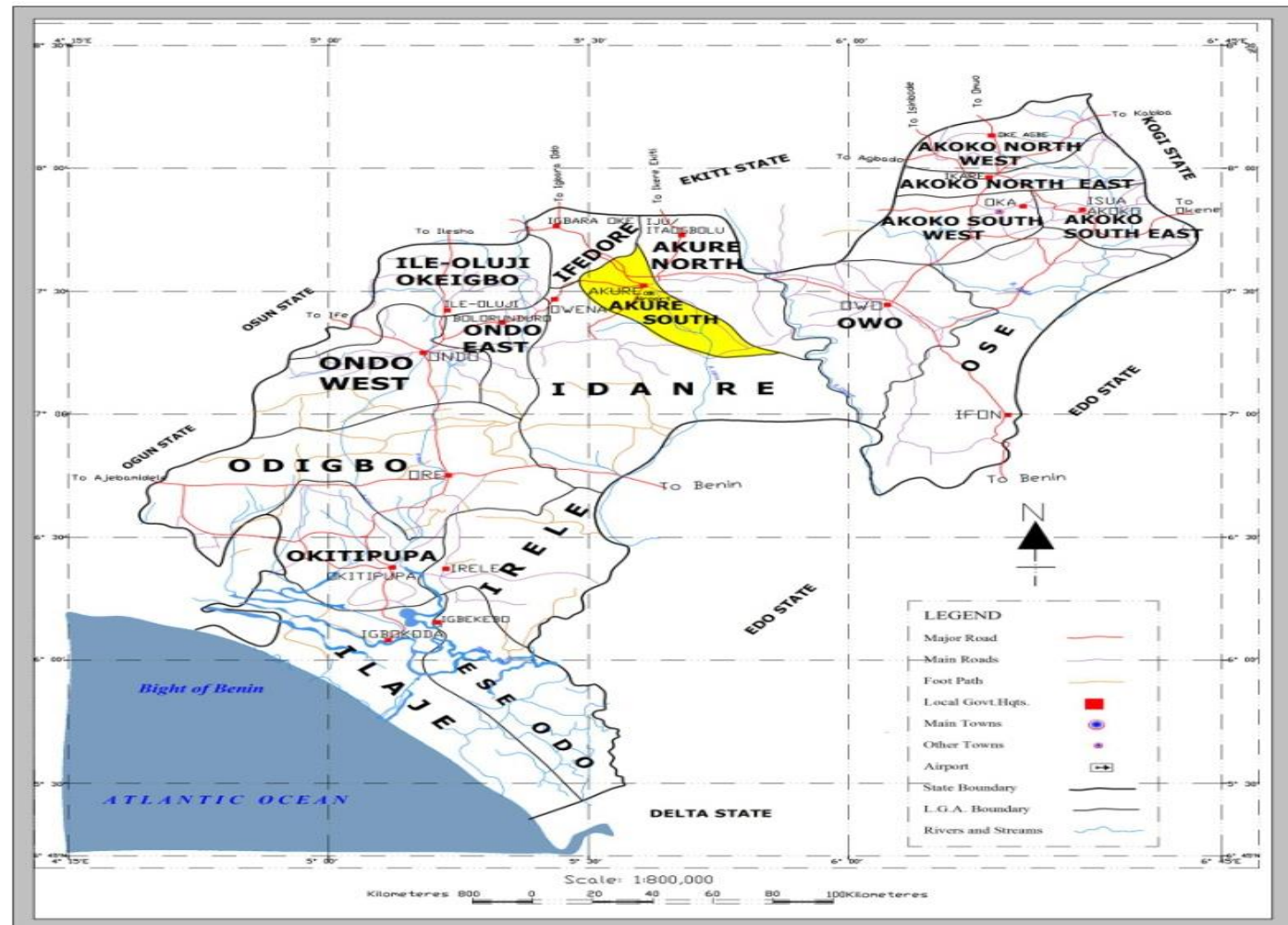

Figure 2. Ondo State Showing Akure south local government area.

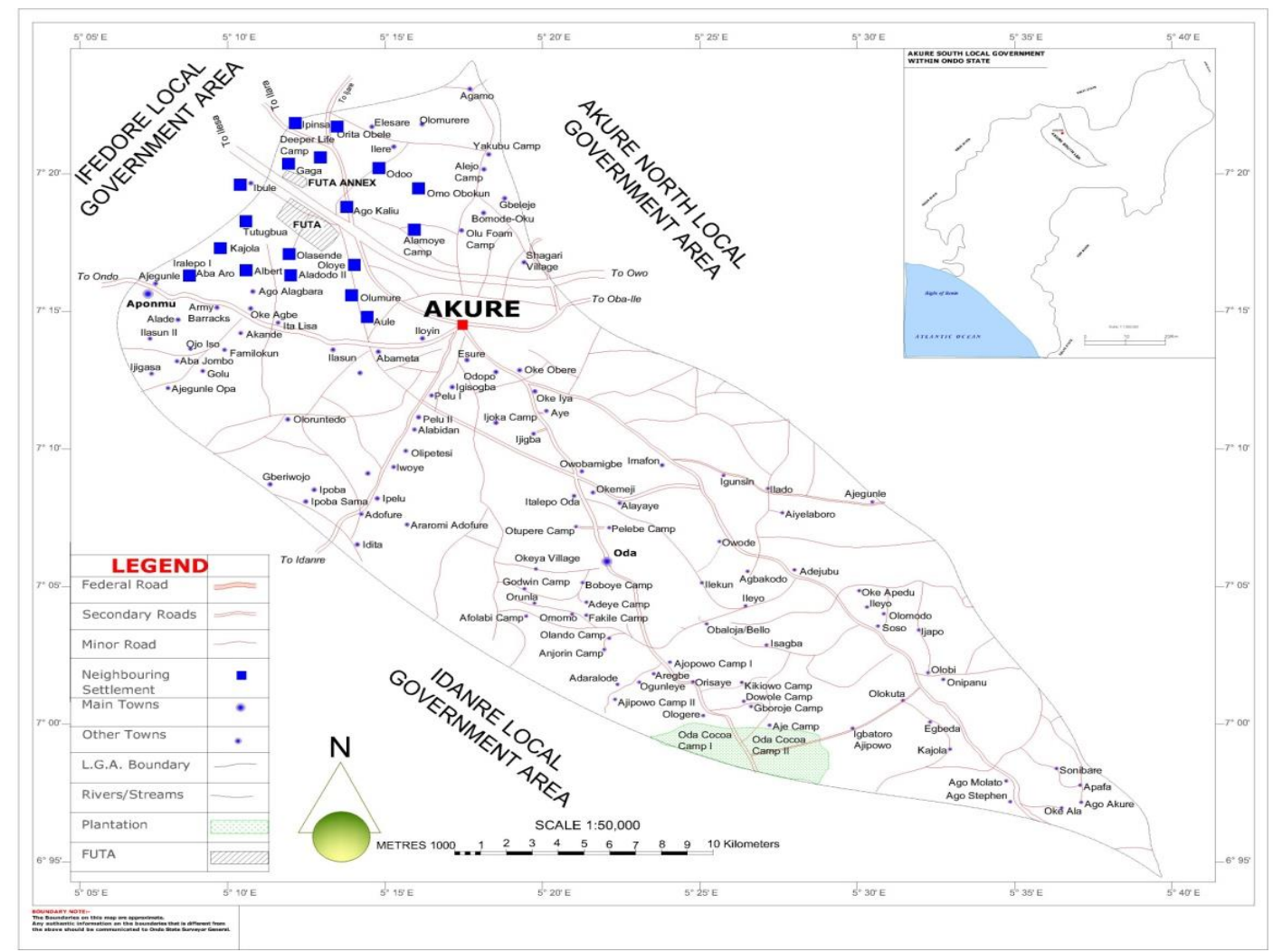

Figure 3. Map showing the location of the study area. 
Akure is the host town of the study area 'Federal University of Technology, Akure (FUTA)' a protected academic area. It is geographically georeferenced on coordinate lines of $734393 \mathbf{E}$, $808614 \mathrm{~N}$; on the western flank and $737291 \mathbf{E}$, $806714 \mathrm{~N}$ on the Eastern flank of meridians. Down to the south is Aule Community; up in its north is Ipinsa Community Lands interpose by Akure-Ilesa Express way, on the west Ilara and Ibule settlements while to the east is southern part of Akure Metropolis ; all these areas are made up of FUTA environs ( see
Figure 4). As at today, Federal University of Technology is composed of School of Environmental Technology, School of Engineering Technology, School of Agriculture and Agric Engineering, School of Earth Sciences, School of Sciences, Senate/Administrative structures and staff secondary/primary school. It is located on a relatively plain land with minor undulations. Average Area coverage around FUTA for the study was 5 kilometers distant in radii.

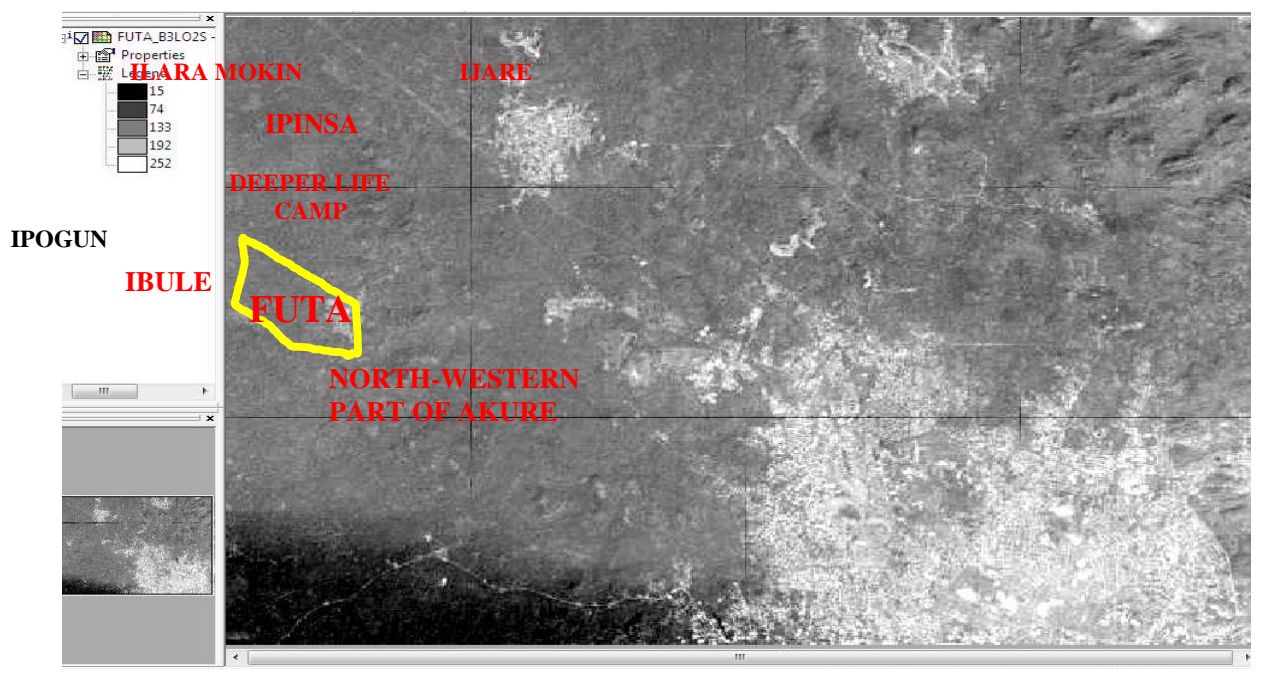

Figure 4. Satellite imagery of FUTA and its environment capture using quick bird.

\section{Data Acquisition and Method}

Satellite imageries of the study area (FUTA) for 1986, 2002 and 2012 were acquired and interpreted with the use of ILWIS GIS software (academic version) to map the urban spatial expansion. This involves the analysis from multispectral satellite images with emphasis on the spectral signature of the images. A supervised classification with a Maximum Likelihood Algorithm used to classify the land use and land cover classes; Built-up areas, Bareland, dense forest, forest reserves, galley forest, light forest, exposed soil and rock out crop. Supervised classification is based on the knowledge of the area. Such knowledge was derived from the field work or the study of the detailed map of the study area. The questionnaire method was used to generate attribute data to further enhance the information on the study area. The research target population is 16,549 for the student and the staff of the university, protected academic area and FUTA environs which are constituted by house owners/ representatives and traders. The sample size was calculated on the basis of average house hold size of 8 persons. The average household size was used to divide the total population to determine the sample size. Thus, percentage of the population sample size produced the number of questionnaire to administer. The percentage used in determining number of questionnaire ranges between $2-5 \%$ of the sample population. The breakdown of the selected number of questionnaire is expressed as:

\section{Population Sample Size = TotalPopulation/ AverageHouseSize}

Number of Questionnaires administered $=$ chosen percentage of the population sample size. This is however mathematically expressed as 3041/8. Therefore, $3 \%$ of the sample population (3868) was severed with questionnaire in the study area. This requested to 116 respondents. Random sampling technique was used to distribute the questionnaire. The areas covered by the questionnaire include 
FUTA campus, Aule community, Ipinsa community lands, Ibule village and Resque / Titibiti community areas respectively. The questionnaire was designed to determine the driving force behind the spatial expansion of FUTA. The areas covered by the questionnaire include socioeconomic status, demographic and geographical data of the study area. All these questions were carefully analyzed and considered in addition to spatial information from the GIS analysis to arrive at our conclusion.

\section{Results and Discussion}

Figures 5, 6 and 7 showed the results of the various processing itemized for the Landsat $\mathrm{TM}$ and Enhanced Thematic Mapping $\left(\mathrm{ETM}^{+}\right)$data sets. Also, Tables 1, 2 and 3 showed the statistical results of the classification of the data set.

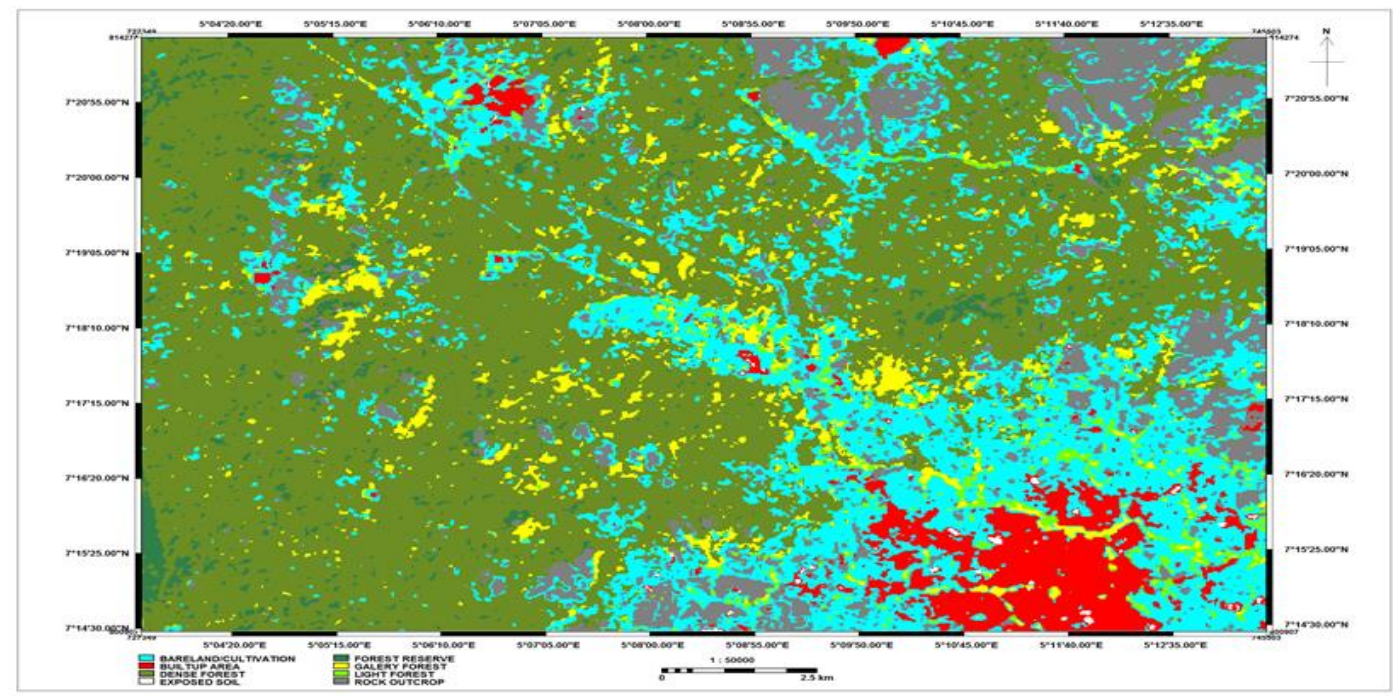

Figure 5. Classified Landuse Landcover Change Map of FUTA and Its Environs in 1986.

Table 1. Statistical Result of Landuse Landcover Map of FUTA and Its Environs in 1986.

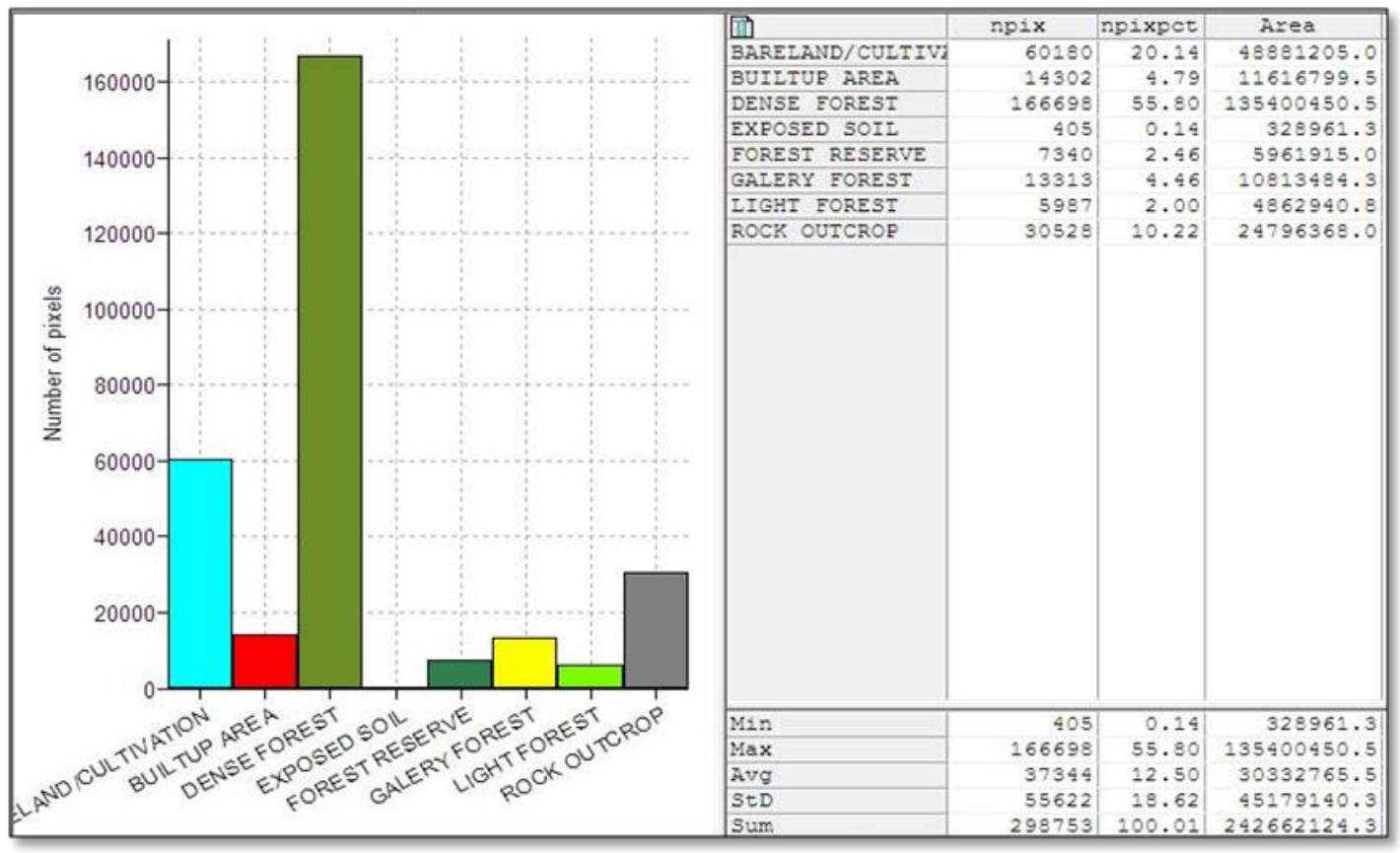




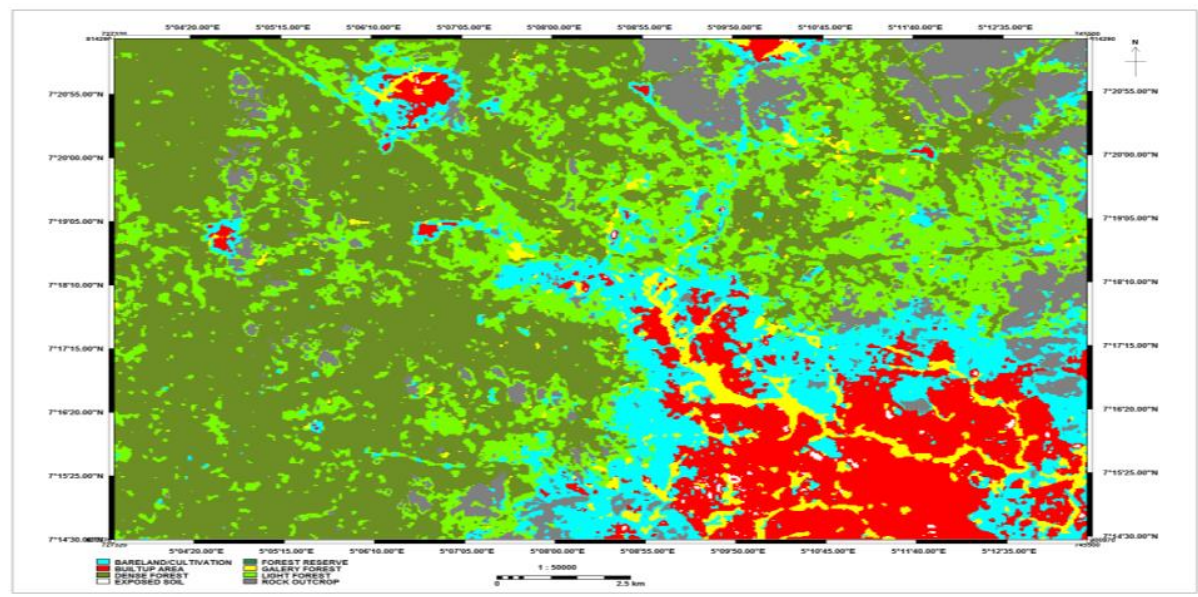

Figure 6. Classified Landuse Landcover Change Map of FUTA and Its Environs in 2002.

Table 2. Statistical result of classified Landuse . Landcover change map of FUTA and its environs in 2002.
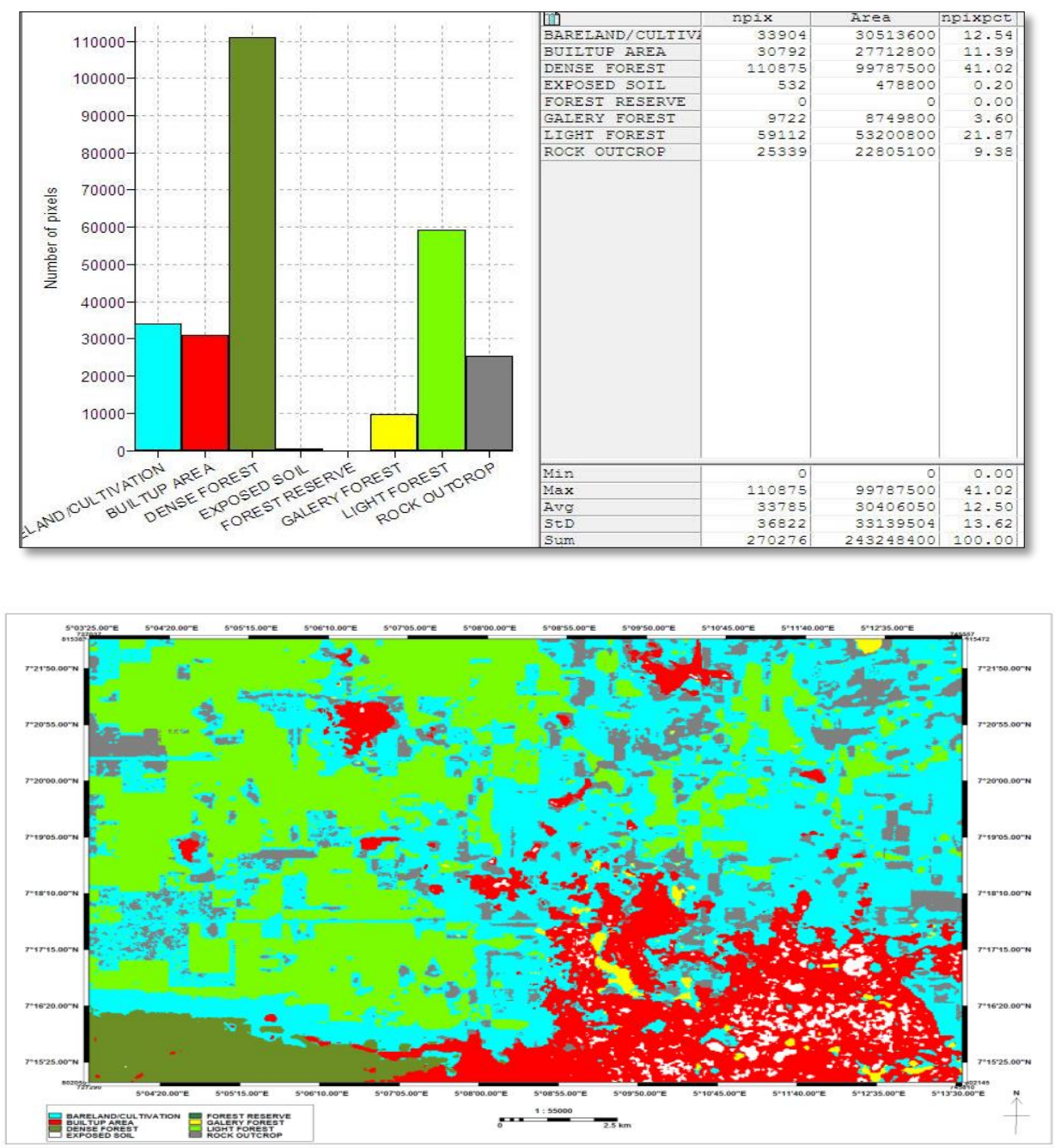

Figure 7. Classified Landuse Landcover change map of FUTA and its environs in 2012 . 
Table 3. Statistical Result of Classified Landuse Landcover Change map of FUTA and Its Environs in 2012.

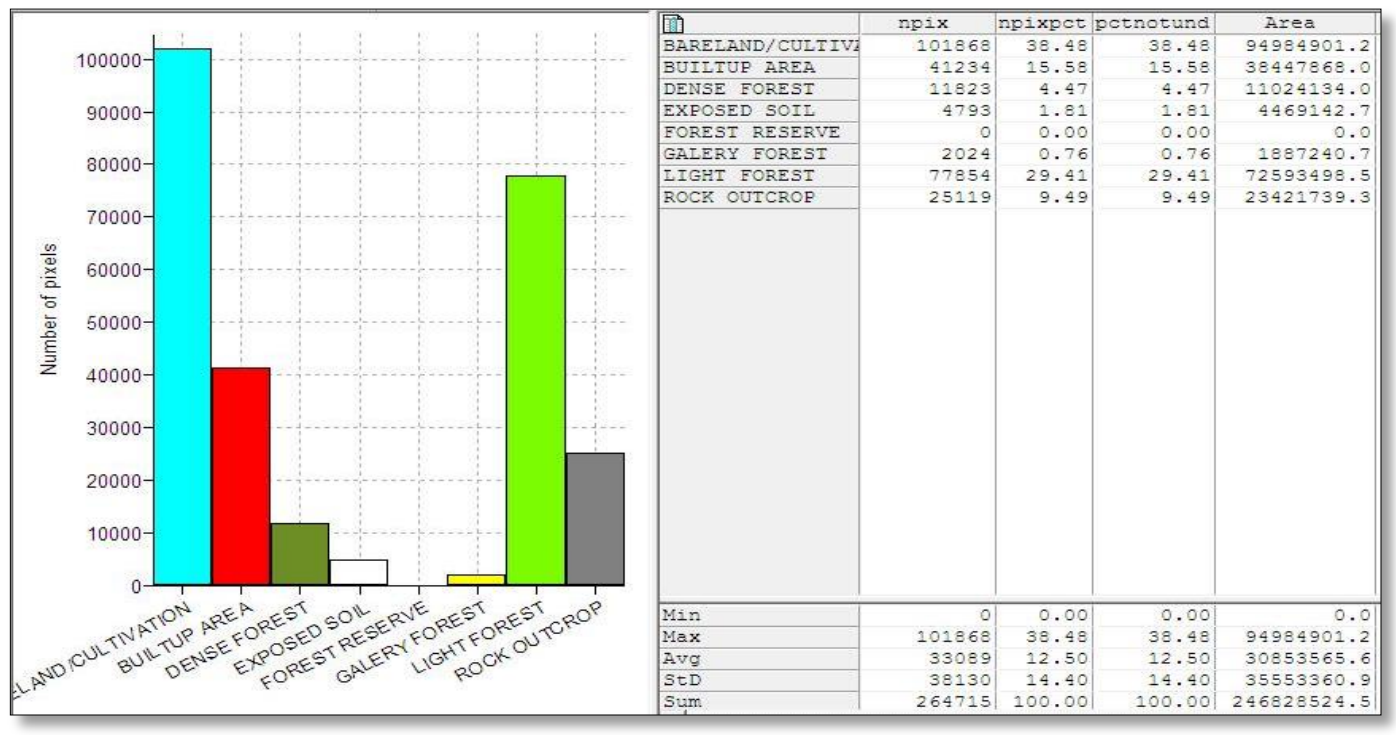

A supervised classification was performed on reflective bands (bands 4, 5 and 7) into the following 8 landuse/landcover classes; Urban (Built-up), Dense Forest, Bareland/Cultivation, Exposed Soil, Forest Reserve, Gallery Forest, Light Forest and Rock Outcrop. The classification results of Figures 5, 6 and 7 however showed remarkable differences as evidenced on Tables 1, 2 and 3. On comparing the Figure 5 and Table 1 it was observed that densed forest covers the largest land area of 13,540 hectares $(55 \%)$ of the total land area of study. Bare land/Cultivation covers 4888.125 hectares (20\%), while, built-up area was 1161.67995 hectares $(4.79 \%)$ of the total land area of study in 1986. This information reveals that people had not tampered with vegetative covers in terms of agricultural landscapes and natural vegetation. Construction/land use development was bare minimum.

Figure 6 and Table 2 shows that almost all classes are changing to one another but more significantly to built-up, light forest and bareland/cultivation followed by exposed soil. Forest reserve disappeared in after 16 years, having lost to light forest which has landcover increase of 457.07 hectares to compare to 1986 land cover figures. Bare land/Cultivation class has a short fall of 1836.76 hectares, while, built-up area class increased in landuse size to 2771.28 hectares $(11.39 \%)$. This result indicates that green covers are gradually disappearing thus posing threat to biodiversity in 2002.

In 2012 expansive Built-Up area is more pronounced than what it was in 2002. Though, forest reserve had disappeared but light forest keeps increasing as dense forest is rapidly losing to light forest. In Figure 7 and Table 3, dense forest had decreased to 1102.41 hectares (4.47\%), light forest 7259.35 hectares (29.41\%), Bare land/Cultivation had increased to 9498.49 hectares $(38.48 \%)$. This has been attributed to government intervention on campaign for agricultural practices such as Fadama programmes, campaign for tree planting across the world and particularly in Nigeria. Between 2002 and 2012 , dense forest lost $88.96 \%$ of its land cover to light forest.

\section{Exponential Growth Rate}

The exponential growth formulae; $\mathrm{Af}=\mathrm{Ab}(1+\% / 100)$ $\mathrm{f}-\mathrm{b}$, (where $\mathrm{A}$ is the future, $\mathrm{b}$ is the base year and $\%$ is the rate of change for projecting urban expansion and landuse type or to project the growth and landcover change of the study area to year 2032.

For instance: where Original Built-Up Area (Landuses) is 3844.79ha with an estimated growth rate of $3.83 \%$ per year, 1 is constant; the expected total Built-Up Area after 20 years can be calculated as follows:

$$
\begin{aligned}
& \text { Af }=3844.79(1+3.83 / 100 * 20) \\
& \text { Af }=6789.90 \text { hectares }(176.6 \% \text { Landuse gain }) .
\end{aligned}
$$

Percentage growth rate is very important to be calculated through absolute changes at interval of time to realize target results of exponential growth. In the view of this, percentage increase is calculated by dividing absolute change by initial time values multiply by 100 . Therefore, rate of change will be determined as follows: Percentage increase divided by the number of years $(n)$. 
Table 4. Rate of Change of Land use/Land cover area between 2002 and 2012.

\begin{tabular}{|c|c|c|c|c|c|}
\hline CLASS & 2002 & 2012 & $\begin{array}{l}\text { Absolute } \\
\text { Change }\end{array}$ & $\begin{array}{l}\text { Percentage } \\
\text { Increase }\end{array}$ & Rate of Change \\
\hline $\begin{array}{l}\text { Bareland/ } \\
\text { Cultivation }\end{array}$ & 3051.36 & 9498.49 & 6447.13 & 211.3 & 21.13 \\
\hline $\begin{array}{l}\text { Built-Up Area } \\
\text { (Landuses) }\end{array}$ & 2771.28 & 3844.79 & 1073.51 & 38.7 & 3.83 \\
\hline Dense Forest & 9978.75 & 1102.41 & -8876.34 & -88.9 & 8.89 \\
\hline Exposed Soil & 47.88 & 446.91 & 399.03 & 833.4 & 83.34 \\
\hline Forest Reserve & 0 & 0 & 0 & 0 & 0 \\
\hline Gallery Forest & 874.98 & 188.72 & -686.26 & -78.4 & 7.84 \\
\hline Light Forest & 5320.08 & 7259.35 & 1939.27 & 36.5 & 3.65 \\
\hline Rock Outcrop & 2280.51 & 2342.17 & 61.66 & 2.7 & 0.27 \\
\hline
\end{tabular}

The table below shows spatial prediction of 20 years taking cognizance of the exponential functions. Recalling the formulae: $\mathbf{A f}=\mathbf{A b}(\mathbf{1 + \% / 1 0 0 )} \mathbf{f}-\mathbf{b})$.

Table 5. Exponential prediction of land use land cover change for 20 years.

\begin{tabular}{|c|c|c|c|c|}
\hline CLASS & $\begin{array}{l}\text { AreaHa } \\
\text { Y0 }\end{array}$ & $\begin{array}{l}\text { Grow } \\
\text { Perc }\end{array}$ & $\begin{array}{l}\text { AreaHaY20 } \\
2032\end{array}$ & $\begin{array}{l}\text { Comments/ } \\
\text { Remarks }\end{array}$ \\
\hline $\begin{array}{l}\text { Bareland/ } \\
\text { Cultivation }\end{array}$ & 9498.49 & 21.13 & 49639.11 & $\begin{array}{l}40140.62 \text { ha gain from dense forest, light forest and Gallery } \\
\text { forest }\end{array}$ \\
\hline $\begin{array}{l}\text { Built-Up Area } \\
\text { (Landuses) }\end{array}$ & 3844.79 & 3.83 & 6789.90 & $\begin{array}{l}\text { 2945.11hectares gain precisely from Bareland/Cultivation } \\
\text { class }\end{array}$ \\
\hline Dense Forest & 1102.41 & -8.89 & -3062.50 & $\begin{array}{l}\text { Dense forest has completely lost to light, then to Bareland } \\
\text { /Cultivation with negative sign equivalent to nothing but zero. }\end{array}$ \\
\hline Exposed Soil & 446.91 & 83.34 & 7896.00 & $\begin{array}{l}\text { 7449.09hectares of land has been exposed due to } \\
\text { construction, quarry, mining and other physical developments }\end{array}$ \\
\hline Forest Reserve & 0 & 0 & 0 & Zero forest reserved is experienced. \\
\hline Gallery Forest & 188.72 & 7.84 & -484.63 & $\begin{array}{l}\text { There is tendency that the gallery forest would have totally } \\
\text { given way for Cultivation /farming activities like FADAMA } \\
\text { Projects. }\end{array}$ \\
\hline Light Forest & 7259.35 & 3.65 & 7260.35 & Light forest almost disappearing. \\
\hline Rock Outcrop & 2342.17 & 0.27 & 2468.65 & $\begin{array}{l}\text { Rock Outcrop remains slightly unchanged due to low rate of } \\
\text { industrial exploitation and mining. }\end{array}$ \\
\hline
\end{tabular}

\section{Population Growth of FUTA and its Socio-economic Implications on the Surrounding Environment}

The institution has haphazardly expanded outwards depleting cultivated land and vegetation in the fringe, particularly at the central part of the study area specifically towards the North western part of Akure Township. This is most likely due to the fact that people are encroaching into this part of the study area for purposes such as building, trading and commerce, quarry, construction, blasting and mining.

Indeed, between the period of 2002 and 2012, there has been rapid increment in the spatial expansion of the study area compared to the period between 1986 and 2002. There is a possibility of continual increment in this area over the next $20 \mathrm{yrs}$. This may therefore suggest that land covers are continually disappearing in the study area. This would have impacts on a wide range of environmental and landscape attributes including the quality of water, land and air resources, ecosystem processes and function, and the climate system itself through greenhouse gas fluxes and surface albedo effects. Continuous global warming and destruction of bio-diversities in the ecosystem will definitely become the order of the day.

Besides, coming to the central part of the area of study as a sample site for in-depth study, developmental spread from the eastern side of FUTA precisely from North western Akure is another point of note. In fact, there have been several house owners who have converted their residential units to student hostels without considering regular space standards. Open space and setbacks to road have been 
considered good areas to build more hostels and commercial shops. The result of this is development an urban slum around a protected academic area.

There is likely going to be crowdedness brought by compactness in and around FUTA come 2032. This situation will have negative implications in the area because of the associated problems of complexity of urban land use such as crowdedness like crime, poor housing, poor socio-economy and easy spread of diseases. Other variables that are responsible for spatial expansion of the institution include: occupational status, construction of buildings, year the buildings were erected, and demand for accommodation and land values amongst others (see tables 6-10).

The Table 6 revealed that from 116 respondents, students took $62.1 \%$ of the total respondents, followed by Business/Trading with a total of 26 $(22.4 \%)$ of the total respondents; civil servant stood at $6.9 \%$ of total respondents, followed by artisan/professionals and farming with $5.2 \%$ and $2.6 \%$ respectively. This however shows that students' population dominates highest percentage around the campus environment, while traders follow the dominant ratio.

Table 6. Occupational status.

\begin{tabular}{lcc}
\hline \multicolumn{1}{c}{ Variable } & Frequency & Percentage \\
\hline Unemployed & 1 & 0.9 \\
\hline Farming & 3 & 2.6 \\
Business/Trading & 26 & 22.4 \\
Artisan/Professional & 6 & 5.2 \\
Civil Servant & 8 & 6.9 \\
STUDENTS & 72 & 62.1 \\
Total & 116 & 100.0 \\
\hline
\end{tabular}

Establishment of Federal University of Technology, Akure has caused rapid expansion in the central part of the study area as there is continuous construction of both residential and commercial buildings to meet the needs of students and to serve the community. Table 7 shows that between 1990 and 1998, there was $17.3 \%$ increase in building construction that is rising up from $10.3 \%$ to $27.6 \%$. In $2006-2012$, there was balance in the construction of building. It is believed that this has been caused by the increase in the cost of building materials and construction services

Table 7. Showing the year existing buildings were erected.

\begin{tabular}{ccc}
\hline Year & Frequency & Percentage \\
\hline $1982-1990$ & 12 & 10.3 \\
$1991-1998$ & 32 & 27.6 \\
$1999-2006$ & 36 & 31 \\
$2006-2012$ & 36 & 31 \\
Total & 116 & 100 \\
\hline
\end{tabular}

Table 8 indicates that provision of residential units for students' accommodation is continuous till date, though at a balanced percentage rate. This has been attributed to high demand for residential accommodations around the campus due to inadequate supply of hostel accommodation on campus.

Table 8. Demand for accommodation.

\begin{tabular}{lrrrr}
\hline Session & Population & General Increase & \% increase & Annual Increase \\
\hline $1990 / 91$ & 2511 & - & - & \\
$1995 / 96$ & 5730 & 3219 & 128.0 & 25.6 \\
$2000 / 01$ & 10085 & 4355 & 76.0 & 15.2 \\
$2005 / 06$ & 14243 & 4158 & 41.5 & 8.3 \\
$2009 / 10$ & 18412 & 4169 & 29.5 & 5.9 \\
\hline
\end{tabular}


Increase in the value of Landed properties had been prompted due to high commercial activities and high demand rate for residences around the institution. It has been observed that since the establishment of the Federal University of Technology, Akure which has attracted a large number of people toward it, Rental value of landed properties have been rising. Table 9 shows that value of a plot of land around the institution is high. Plot sold at N900, 000 or more covers $51.7 \%$ as the largest percentage of the respondents' claims. Those areas where land is sold below N750, 000 are very far from the campus vicinity. This is the area where building arrangement is scattered and not clustered.

Table 9. Estimated Cost of Plot in FUTA environment.

\begin{tabular}{lcc}
\hline Cost Of Plot & Frequency & Percentage \\
\hline N450,000-N600,000 & 8 & 6.9 \\
N600,000-N750,000 & 24 & 20.7 \\
N750,000-N900,000 & 24 & 20.7 \\
Above N900,000 & 60 & 51.7 \\
TOTAL & 116 & 100 \\
\hline
\end{tabular}

\section{Conclusion and Recommendations}

The study has highlighted the spatial growth of Federal University (FUTA) and its implication on the surrounding environment. It has also identified some the factors that contributed to this spatial expansion in the study area.

The spatial expansion of the study area stills continue to be at a fast rate. This is not that concerned authorities have not been planning for spatial/urban growth and the problem generated by it, but that the sustainable landuse pattern could not accommodate the continuing spatial expansion on the vegetative covers which serve as protective habitat for wide range of environmental and landscape attributes. Indeed, between the period of 2002 and 2012, there has been rapid increment in the spatial expansion of the study area compared to the period between 1986 and 2002. There is a possibility of continual increment in this area over the next $20 \mathrm{yrs}$. This may therefore suggest that land covers are continually disappearing in the study area. This would have impacts on a wide range of environmental and landscape attributes including the quality of water, land and air resources, ecosystem processes and function, and the climate system itself through greenhouse gas fluxes and surface albedo effects. Continuous global warming and destruction of bio-diversities in the ecosystem will definitely become the order of the day. There is likely going to be crowdedness brought by compactness in and around FUTA come 2032. This situation will have negative implications in the area because of the associated problems of complexity of urban land use such as crowdedness like crime, poor housing, poor socio-economy and easy spread of diseases This research work demonstrates the ability of GIS in monitoring spatial changes. The result of the work shows a rapid growth in built-up land between 1986 and 2002 while the periods between 2002 and 2012 also witnessed a reduction in this class. After the initial reduction in farm land between 1986 and 2002, the study area has witnessed a steady growth of landuse development culminating to great decrease in farmlands, forest reserve and dense forest. Indeed, in 2012, the result showed that there was great loss of agricultural lands, and it may continue in this trend in 2012 to 2032 all things being equal.

This study therefore advances some recommendations as a way of reducing the spatial expansion in the study area. There is need to encourage urban agriculture to create a sustainable environment, maintain quality of environment, create employment, provide much food and aesthetics to serve as additional economic nutritional base. It becomes imperative for federal, state, and local governments in making sure that farming and urban agriculture is encouraged since this will lead to food security and more importantly, it will be a source of revenue to the national GDP.

Forest land has been steady in reduction between 1986 and 2002, thus signifying a desirable change and indeed; if this moderate change reduction in forest land observed in-between 1986 and 2002 is upheld to be for next 20 years. Effects of global warming on our environment will be negligible. There is need to generate digital database for landuse/ landcover spatial change. Geographic information on spatial change and other geographic data can be stored and accessed for policy decision making. This will serve as a brain box for policy makers not only in physical and urban planning but for other professions. Public enlightenment on the need for securing plan approval before carrying out any physical development is also important. Securing plan approval will reduce uncoordinated building arrangement in our environment and reduce slums. 


\section{References}

Adeboyejo \& Abolade (2006). Analysis of Spatial changes in Ogbomoso City; Journal of the NITP, Vol. XIX No 1, 40 th Anniversary issue, 35-47

Carol A. Gotway Crawford \& Linda J. Young. (2006). Expanding the "S" in GIS: Statistics and Spatial Support; National Center for Environmental Health, Centers for Disease Control and Prevention; Department of Biometry, University of Nebraska-Lincoln.

John R. Jensen, Dave Cowen, Sunil Narumalani, \& Joanne Halls (2003). Principle of Change Direction Using Digital remote sensor data; Integration of Geographic Information System and Remote Sensing, Edited by Jeffrey L. Star, John, E. Estes, Kenneth C. McGwire. Cambridge University Press.

National Population Commission (1996). Population of the Federal Republic of Nigeria. Analytical Report at the National level, Abuja

Olisa, B.S. (2012). Integrating Spatial Statistics and Geographical
Information System (GIS) In Monitoring Spatial Expansion Federal University of Technology, Akure and its Environments.PGD Thesis Department of Urban and Regional Planning, Federal University of Technology, Akure. Peng, G. \& Howarth, P. (2004). The use of Structural Information for Improving Land cover classification Accuracy at RuralUrban Fringe. Photogrammetric Engineering and Remote Sensing 56( 67-73).

Weng, Q. (1999): A remote Sensing- GIS Evaluation of Urban Expansion and its impact on Surface Temperature in the Zhujiang Delta, China. International Journal, Remote Sensing, 22(10)

Zhi-Yong Yin, Dona J. Steward, Stevan Bullard, Jared T. MacLachlan (2005). Changes in Urban -up surface and Population distribution Patterns during 1986-1999. A Case study of Cairo, Egypt, Computer, Environment and Urban System

Zubair, A.O. (2006). Change Detection in Land use and Land cover Using Remote Sensing Data and GIS (A case study of Ilorin and its environs in Kwara State.) The Department of Geography, University of Ibadan, Nigeria 